\title{
A social perspective on the Neolithic in western Iran
}

\author{
Hojjat Darabi \\ Department of Archaeology, Razi University, Kermanshah, IR \\ h.darabi@razi.ac.ir
}

\begin{abstract}
While the Neolithic revolution caused gradual basic changes in different dimensions of human life, including social structure, western Iran has so far mostly received attention in terms of the emergence of domestication and sedentarisation. Generally speaking, some evidence, such as architectural elements, burial goods, clay tokens, and scarce artefacts such as obsidian pieces and marble objects not only determine an inter-regional interaction, but also suggest craft specialisation. It is believed that sedentary life and private food storage paved the way for property ownership and that a gradual change from egalitarian to non-egalitarian societies can be seen in the Neolithic of western Iran.
\end{abstract}

IZVLEČEK - Medtem ko je neolitska revolucija povzročila postopne osnovne spremembe v različnih dimenzijah človeškega življenja, tudi v družbeni strukturi, je območje zahodnega Irana deležno pozornosti predvsem zaradi pojava domestikacije in sedentarizacije. Posplošeno, nekateri podatki, npr. arhitekturni elementi, grobni pridatki, glineni žetoni in redki artefakti iz obsidiana in marmorja, ne določajo le med-regionalne interakcije ampak tudi specializirane obrti. Verjamemo, da sedentarni način življenja in privatno shranjevanje hrane predstavljata osnovo za privatno lastništvo, in da lahko v času neolitika na območju zahodnega Irana opazujemo postopen prehod med egalitarno in neegalitarno družbo.

KEY WORDS - Neolithic; social structure; initial complexity; western Iran

\section{Introduction}

Since the time when Gordon V. Childe (1936) referred to the transition from the late Pleistocene to the early Holocene as the 'Neolithic revolution', this issue has primarily received attention in the light of changes in subsistence, i.e. foraging to farming. In the 1960-70s, processualist archaeologists focused on the interaction of humans with the environment which moved forward the economic dimension of the most crucial revolution in human history, as Ofer Bar-Yosef (2001) puts it. The Neolithic revolution, however, was not only a change in subsistence from foraging to farming; it also affected the social structure of those people who took the first steps into a new world that had never been experienced before. In archaeological theory, the central importance of the social emerged mainly over recent decades (Hodder 2007). Social archaeology is the archaeology of society, and so encompasses a very wide range of topics (Dark 1995. 88 ). Basic questions posed by the social archaeologist concern social order, reproduction and social change (Shanks 2005.179). It could be expected that alongside subsistence, social structure was changed by the onset of the Holocene, when new ways of life emerged; nevertheless, the economic results have been acknowledged much more than other dimensions of the Neolithic revolution. However, some investigations have recently begun to explore the nature of changes in social organisation in this period. Therefore, archaeologists are now directing new attention to the social context of Neolithic life at the household, community, and regional scales (see Pollock et al. 2010; Byrd 1994; 2000; 2005; Flannery 1972; Voigt 2000; Kuijt 2000; Kuijt, 
Goring-Morris 2002; Goring-Morris 2000; Bar-Yosef, Belfer-Cohen 1991; Cauvin 2000). Collectively, these investigations offer an alternative perspective on the Neolithic transition by shifting the point of debate from questions of how and when plant and animal domestication occurred to what the nature of Neolithic social organisation was throughout this period, and how might these social frameworks have been linked with new systems of food production (Kuijt 2000.311-312). On the one hand, the examination of the social structure of early Neolithic societies is restricted mainly to the Levant (see Flannary 1972; Byrd 1994; 2000; Kuijt 2000; Kuijt, GoringMorris 2002; Ali 2010) and Anatolia (Rosenberg, Redding 2000; Bleda, Marciniak 2006; Pearson et al. 2013; Wright 2014), since the data set for the region is the strongest across the Near East. On the other hand, some other areas, like western Iran, have been very poorly targeted in this regard, although new evidence sheds new light on the Neolithisation process in the region (see Darabi 2012; 2015; Matthews et al. 2013a; 2013b; Riehl et al. 2012; 2013; 2015). In western Iran, however, previous investigations mainly focused on the subsistence issue and, thus, the social consequences of the Neolithisation process are largely overlooked. This resulted from the fact that the region was initially targeted by researchers who concentrated primarily on early domestication (see Braidwood 1960; 1961; Braidwood et al. 1961; Hole et al. 1969; Mortensen 1974; 2014; McDonald 1979; Smith 1972; 1976; Pullar 1990), while it should be seen as a geographic-cultural zone wherein early socio-cultural developments were established as an inter-connected 'whole' in the early Neolithic.

Therefore, this article should be regarded as an introduction to the social consequences of Neolithisation and the social indications of Neolithic societies in western Iran. This is dealt with on a general regional scale, so the elucidation of the social daily life of any particular Neolithic site as already applied to Toll-e Bashi, Fars (see Pollock et al. 2010) - is not attempted here. In fact, a social interpretation of some archaeological finds from Neolithic contexts is discussed in order to investigate the social structure of Neolithic communities in western Iran. Chronologically, the period under discussion coincided with the Transitional Neolithic through the late Neolithic, $c$. 9500-5500 $\mathrm{BC}$. As taking a regional social perspective is difficult, the targeted archaeological finds might seem to be limited. However, I attempt to present those archaeological data that are interpretable in investigating social structure at the regional level.

\section{Archaeological evidence}

As archaeologists, we are concerned with how social structure extends into material culture, what types of materials are usually targeted, and to what extent. In this regard, many types of data and different attitudes have been employed to try to reconstruct social structure: burial, settlements, artefacts, and human remains (Dark 1995.88). However, within a regional context, different materials could be taken into account. Moreover, each archaeological period may require a particular artefact assemblage. Therefore, settlement patterns, human burials, architectural remains, and artefacts such as tokens, figurines, stone tools, and marble objects are briefly discussed here. In addition, subsistence will also be partly addressed. It is believed that all these, and possibly more, evidence should be investigated as an 'inter-woven whole' to gain insights into the social structures of societies living in the early Holocene era (Fig. 1). To better understand the diachronic change and continuity of social structure, one might prefer to place the issue within chronological

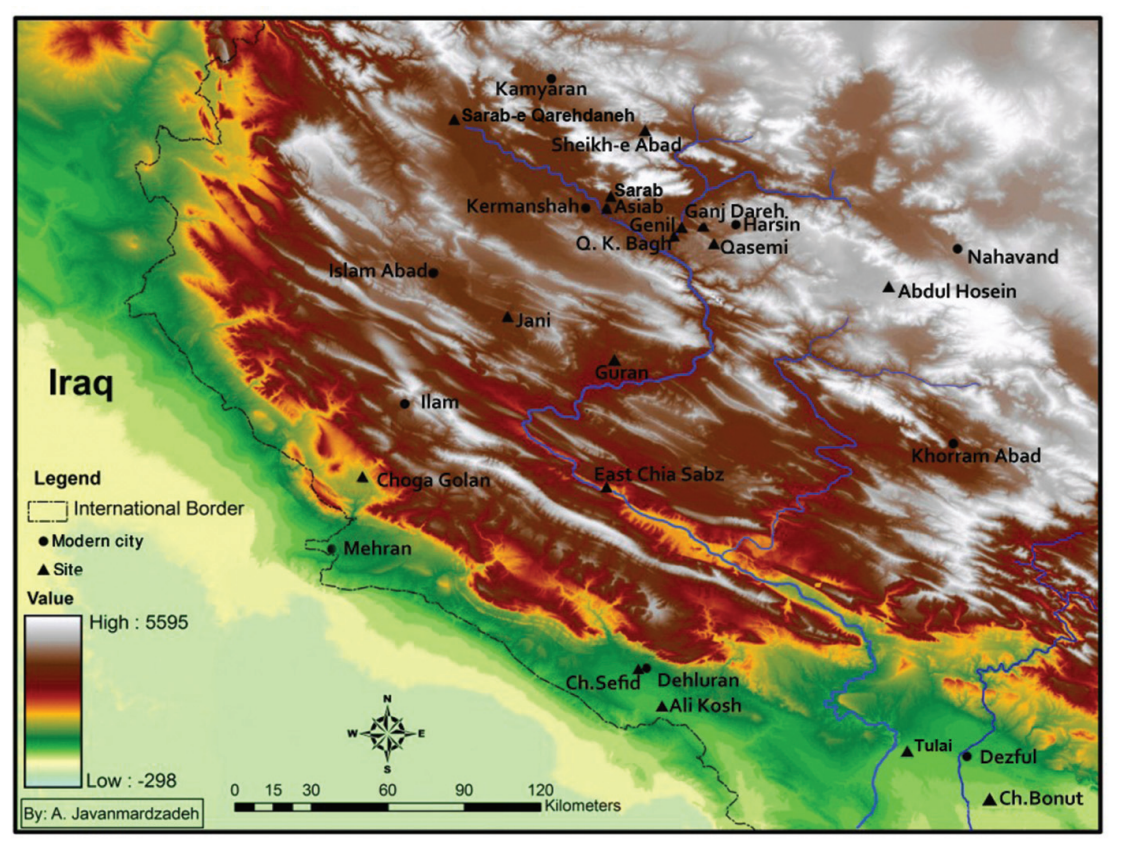

Fig.1. Map showing the location of the main Neolithic sites in western Iran. 
(sub)periods. However, it should be noted that Neolithic archaeology of the region explicitly suffers from limited archaeological evidence, especially in terms of the social dimension. This obliges us to discuss the issue in details from the Transitional Neolithic $(c$. 9500-8000 BC) through the Neolithic period (8000$5500 \mathrm{BC}$ ). However, some archaeological evidence concerning these periods is presented below.

Although any examination of the transitional period requires attention to the preceding Late-Epipaleolithic time, our information is mostly restricted to the lithic tradition which limits our understanding of social structure. In general, we may assume the hunter-gatherer groups were 'small bands' mostly occupied with economic concerns (see Bender 1978).

The evidence associated with the Transitional Neolithic period is limited in western Iran. The time span that we are concerned with involves a gradual change from a migratory to semi-sedentary lifestyle from the mid-10th millennium BC onward, when the climate improved at the end of the Younger Dryas (Darabi 2012; 2015). The scarcity of evidence might be the result of the seasonality of occupations, which left shallow deposits, or they were buried by later sediment or occupations. However, it seems that some sites, such as Sheikh-e Abad and Chogha Golan, were seasonally inhabited in the mid-10th millennium BC. By the early 9th millennium BC, some new occupations, including Asiab, East Chia Sabz, and possibly Sarab-e Qareh Daneh, came about. In addition, Ganj Dareh E and basal Jani might have been given attention. This may indicate some kind of population increase. Although insufficient data remains the main obstacle to debating the social structure of the period, some evidence may be helpful.

From the mid-10th millennium BC, settlements changed from circulating annual movement to circulating semi-permanent (Mortensen 1972; 2014; Darabi 2012; 2015; Weeks 2013). Archaeological data indicate a sort of 'food resource management' in the Transitional Neolithic period (Darabi 2012; 2015). Some particular plant species, including tworow barley, emmer wheat and lentil were cultivated during the $9^{\text {th }}$ millennium BC (Riehl et al. 2012; 2013; 2015). At the same time, goats were also herded (Zeder 2008; 2011). Although a gradual change in subsistence is estimated, data on social structure are still hidden. However, we presume that changes in settlement and subsistence patterns must have occurred alongside changes in social structure.
As a result of changing from seasonal occupation to semi-sedentism, an increase in population must have occurred in the early $9^{\text {th }}$ millennium BC. Therefore, the environmental resources were not sufficient to feed the whole population in the small valleys or intermountain plains such as Konjan Cham or Kurtavij, where Chogha Golan and Sheikh-e Abad were respectively established. This resulted in the diversification of people across western Iran in a way that led to an increase in the number of sites. However, later pressures on resources paved the way for an alternative solution, i.e. food management and, subsequently, the beginning of the Neolithic period. However, the area of the sites is not determined. At Asiab, the surface finds suggested that the site might have extended over an area of approx. 2ha (Howe 1983). As Asiab seems to have also been reoccupied during a later period, perhaps the late $8^{\text {th }}$ millennium BC, the precise area of the Transitional Neolithic occupation is unclear. In addition, the site might have been horizontally extended through time. Excavations at Asiab, however, revealed different finds, such as bone objects, stone tools, stone implements, obsidian tools, marble objects and human burials. Some of these might date to a later phase; however, recent excavation at the site can be helpful in this respect.

One of the most important signatures characteristic of the Transitional Neolithic period are pits, usually dug into virgin soil at the basal levels of sites such as Asiab (Howe 1983.115) and Ganj Dareh E (Smith 1972b.193; 1976.12). Other sites have not yet been excavated sufficiently. At Asiab, a large oval expression found in the lowest layers is regarded as a refuse pit and also a possible semi-subterranean structure. However, the pits seem to have been used for storing food supplies or even parching grain 1 . This arrangement allowed people to remain in one place for a longer period, resulting in population growth. No evidence of privacy or property is seen during the transitional period, although the numerous pits might indicate that each family had separate storage facilities. The first presence of grindstones shows an increasing emphasis on plants. People lived in huts built from perishable materials such as wood and reeds. Therefore, no solid trace of architecture has been found adjacent to the pits. This prevents an estimate of the possible mean population at both home and site levels and how densely populated each site was. If pits indicate an initial property, they probably paved the way for private property or ownership, which is seen in the succeeding early

1 In some areas of the region, such pits were even used until some decades ago, mainly by nomadic people for storing grain. 
Neolithic period, during which several changes seem to have occurred in western Iran: the emergence of morphologically domestic species; the emergence of true villages with solid rectilinear architecture; standardisation of stone tools; development of places for rituals; production of some new objects, such as clay tokens; and the introduction of obsidian tools and marble objects. These innovations can be useful for an investigation of social structure.

In the Neolithic period, ecotones were still the environmental priorities for occupation; especially places close to fresh water or with fertile cultivable soil. It seems that most houses were built of different available materials, including mud (pisê), mud-brick and stone. Buildings are rectilinear in plan, with a small area. They might be seen as the earliest architectural remains; although recent excavation at Tapeh Asiab seems to tell us something different on the circular pise walls, the Neolithic architectural remains must have mostly been preceded by the application of perishable materials. Excavations at upper Sheikh-e Abad and Ganj Dareh D revealed cellular rooms which were linked together to form a complex building. No evidence of foundations is mentioned until the second half of the $7^{\text {th }}$ millennium $\mathrm{BC}$, when some walls were founded on stone in the Deh Luran Plain (Hole et al. 1969; Hole 1977). Two-storey houses have also been attributed to Gnaj Dareh D (Smith 1990). The emergence of public or ritual buildings alongside residential sites is of interest. At upper Sheikh-e Abad, two kinds of architectural traces were found, known as Buildings 1 and 2 (Matthews et al. $2013 a$ ). Building 1 comprises an irregular agglomeration of several rooms made of clay. The rooms are generally rectilinear and oriented south-west/ northeast. The dimensions of rooms are small, ranging from approx. 1.8 to $2.5 \mathrm{~m}$. Outside the buildings, some features were also excavated which have been considered as activity areas or sometimes animal pens. Building 2 comprises a single major room built from shaped mud-bricks, as well as occasional indistinct lumps of pisé. The walls, at approx. $80 \mathrm{~cm}$, are thicker than the walls of building 1 , which are generally 30 to $36 \mathrm{~cm}$ thick. The interior area has a Tshaped plan with, similar to building 1 , with no remains of an entrance. The most important material in the building included skulls, horn-cores, and the maxillae of five wild herbivores (four goats and one sheep) arranged in two pairs with a single sheep skull placed behind the eastern pair (Fig. 2). Traces of red ochre were clearly evident on the maxilla and cheek of a skull positioned in the eastern front part of the assemblage, and as spots on the surface of the floor under the skulls. The distinctive architecture and internal features such as in situ skulls suggest a ritual area at the site (Matthews et al. 2013a).

A ritual site was also discovered at Ganj Dareh D (Fig. 3). Here, a pair of wild sheep skulls had been carefully fixed inside one of the portholes. The architectural features of Ganj Dareh D are so prominent that they have been regarded as 'a futureless innovation' (Smith 1990). Although the evidence that explicitly indicates ritual/non-domestic buildings is confined to these two sites, as recently seen from Tapeh Asiab, more is expected across the region. Some architectural remains indicate an intrasite difference between the houses that have been excavated so far. At Genil, walls were built of large mud-slabs and plastered with mud or white lime, also sometimes used for floors. A large domed structure filled with stones was also discovered (Smith, Mortensen 1980). In one case at Abdul Hosein (Pullar 1990.9-10), a floor had been re-plastered seven times, sometimes with red ochre. However, more prominent evidence comes from Tapeh Guran, where excavations have shown that almost all the floors in levels $\mathrm{K}, \mathrm{J}$, and $\mathrm{H}$ consisted of a mixture of clay and lime with a large number of white pebbles. These floors were made in a kind of 'terrazzo-technique' with large pieces of chalk-spar carefully laid in a solid mortar of ochre-coloured clay (Mortensen 2014.28). Based on the radiocarbon dating and pottery styles, these levels could be dated to around $6000 \mathrm{BC}$. In the lowlands, some mud-brick platforms were un-

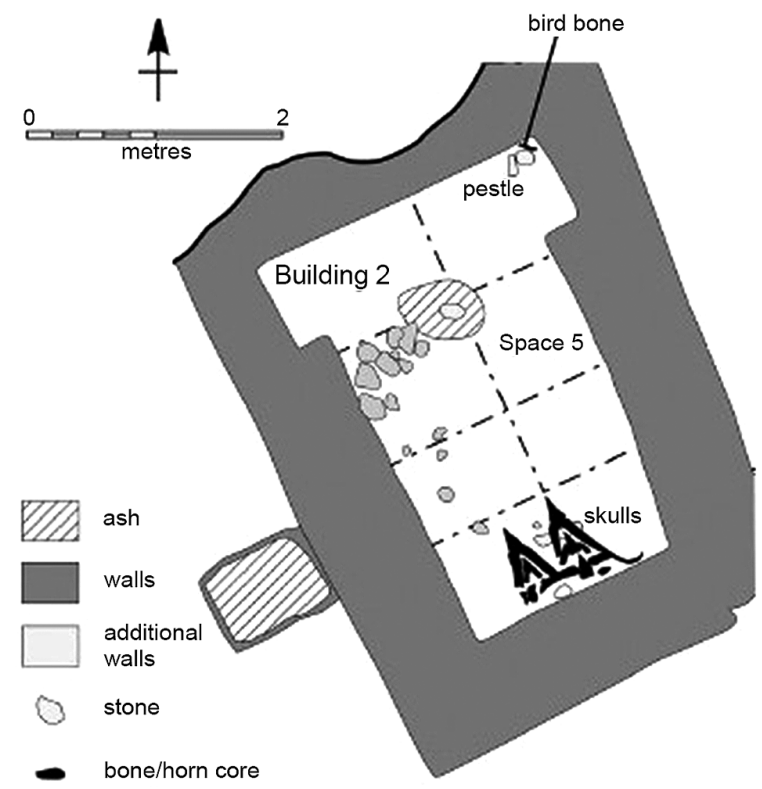

Fig. 2. A ritual building recovered from upper Sheikh-e Abad (adapted from Bendrey et al. 2013. 153, Fig.12.2). 
covered at Chogha Sefid which measure approx. $7 \times 10 \mathrm{~m}$ in size, standing about $1.8 \mathrm{~m}$ high, founded on large stones; they were built of standard mud-brick, $60 \times 30 \times 10 \mathrm{~cm}$ in size $($ Hole 1977).

In addition to the architectural remains, other artefacts such as obsidian tools and marble objects may provide us with informative data. The emergence of obsidian pieces in the region is archaeologically remarkable. Across the Near East, obsidian pieces are entirely attributed to sources in Turkey and the Caucasus (Renfrew 1969; Renfrew, Dixon 1977; Abdi 2004). It seems that the late $8^{\text {th }}$ millennium $B C$ witnessed the first appearance of chipped obsidian tools in western Iran (Darabi, Glascock 2013). This phenomenon might have been associated with the transhumant communities which were moving across the region and perhaps transported the obsidian blanks. This indicates that obsidian was indirectly transported in western Iran. However, the emergence of obsidian, along with marble objects, could indicate an indirect inter-regional contact.

Although the most regularly used approach to reconstructing social structure is perhaps the use of burial evidence (Dark 1995.90), this type of evidence is quite rare in western Iran. In general, burial traditions show continuity through time, with flexed or crouched positions being predominant. In this regard, some samples are accompanied by burial goods. Unlike in the Levant or Turkey, however, individuals were buried entire under floors, and no signs of 'skull removal' or 'skull cache' have been found. As a result of excavations at Asiab, two burials were found, one in a crouched and another in an extended position. Ochre seems to have been applied in association with the latter (Howe 1983.115). At upper Sheikh-e Abad, six burials were found under floors. They had no distinct grave cuts and were accompanied by no obvious grave goods; however, two skeletons seem to have ochre stains. In addition, the remains of a reed mat are also believed to be connected with one find (Cole 2013). In two cases, the burial cut through the walls. This may date the burials to a period later than the architectural remains, including the so-called 'ritual building'. Excavations at Ganj Dareh revealed a notable number of human burials in two crouched and extended positions. They are associated with ages varying from infant to adult. In one case, a multiple burial consisting of three individuals in a clay coffin was discovered from level D (Smith 1972.193; 1976.17). One burial was accompanied by many stone and shell beads. Also, the remains of a reed mat were discovered with one skeleton. Of the two burials found during the first season of rescue excavation at East Chia Sabz, one was accompanied by goods, including a stone bead and a necklace made from perforated land snail shells (Darabi et al. 2011; 2013). A combination of crouched and extended burial customs is also seen at Abdul Hosein, where a stone vessel was found adjacent to a single burial. Moreover, four skeletons were found which, in Judith Pullar's view, might have been buried as the result of a roof collapse (Pullar 1990.10). At Genil, two bodies were buried under the floor in a tightly flexed position and one with possible signs of cranial deformation (Mortensen, Smith 1977; 2014; Smith, Mortensen 1980.511- 
512). Cranial deformation has also been reported from Ganj Dareh and Ali Kosh. In the Ali Kosh phase, some burials were wrapped in a reed mat (Hole et al. 1969.248). In addition, one burial was entirely coated with red ochre. From the succeeding Mohammad Jaffar phase (zone A1), several burials were found, sometimes accompanied by shell and turquoise jewellery, stone beads, and labrets (Hole et al. 1969.47). No evidence
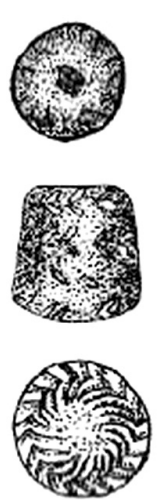
of mat-wrapping was detected in this phase. However, one of the burials had been given more attention, with the most elaborate grave goods, including turquoise beads, a labret of turquoise, a bracelet of white shell beads, strings, and a bell-shaped stone pendant. In addition, the body was completely coated with red ochre (Hole et al. 1969.254). The use of red ochre and reed mats is also seen in the later phase, at the site at Chogha Sefid (Hole 1977). At Guran, a heap of human bones was found in the lowest level. Furthermore, beads have also been reported as burial goods at the site (Mortensen 2014), and two tokens seem to have been used as grave goods (Schmandt-Besserat 1992). Clay tokens have been discovered, but not as grave goods, from other Neolithic sites, such as Ganj Dareh, upper Sheikh-e Abad, upper Asiab, Ali Kosh, Chogh Bonut, Chogha Sefid, Tulai, Sarab, and Abdul Hosein (Fig. 4). They appear from the early $8^{\text {th }}$ millennium $\mathrm{BC}$, when the true Neolithic period began in the region. This period roughly coincided with the development of clay animal and human figurines, as seen from the above-mentioned sites.

All these innovations occurred along with the emergence of new chipped stone types. As the most numerous Neolithic artefacts, stone tools display some standardisation and even craft specialisation. Although the chipped stone industry seems to have derived from the preceding Zarzian tradition (Kozłowski 1994; 1999; Olszewski 1994; 1996), the most prominent change was the beginning of the M'lefatian industry in the Early Neolithic, during which a combination of retouched,
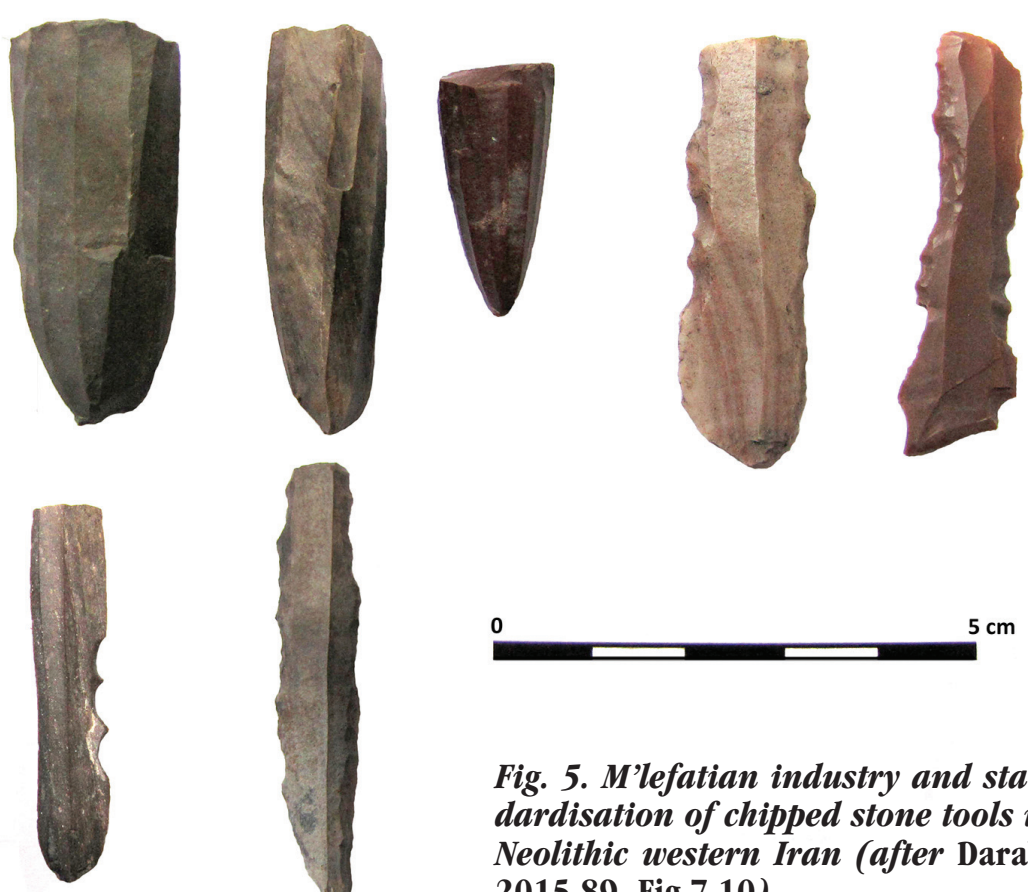
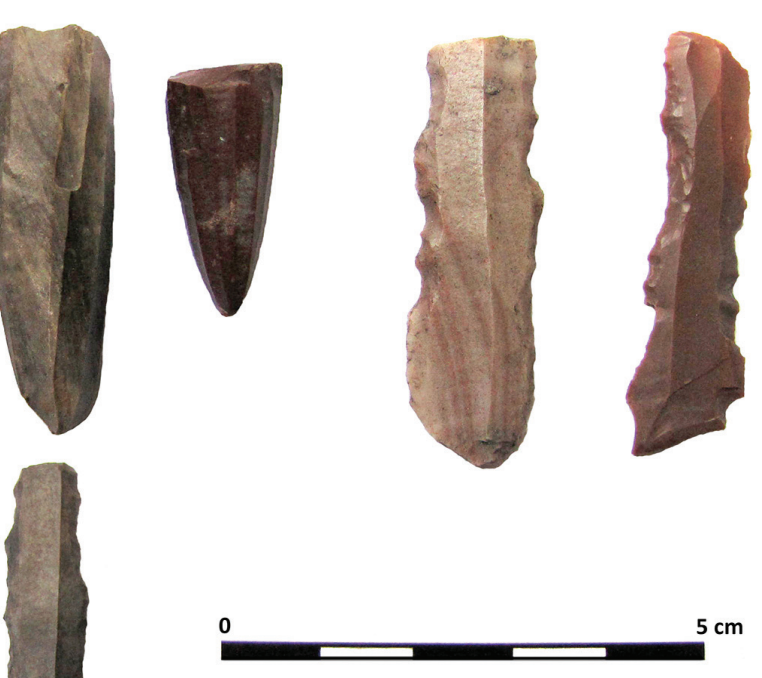

Fig. 4. Clay tokens, which first emerged in western Iran in the $8^{\text {th }}$ millennium BC.

backed, and truncated pieces, including bladelets, blades, and sometimes flakes, along with blade/let cores, are prevalent. However, this industry more or less continued through the Neolithic period (Fig. 5), in which flint-knapping became 'domestic'. In fact, 'the domestication of flint' is an idea suggesting that, unlike in the Paleolithic, the preparation of tools, like a number of other daily activities, was entirely an onsite task inside or outside houses ( $c f$. Mortensen 1988.199; 2014.123). This might be evidence for a specialised task, as seen by standardisation in stone tool production.

\section{Discussion}

In order to assess social structure, a theorisation of material culture is required. Although the social typology of band, tribe, chiefdom, and state has had a tremendous influence on social archaeology (Sahlins 1968; Service 1964), this paper does not attempt to place the Neolithic societies of western Iran in any

Fig. 5. M'lefatian industry and standardisation of chipped stone tools in Neolithic western Iran (after Darabi 2015.89, Fig.7.10). 
of these individual evolutionary models. Instead, the discussion is based on the archaeological evidence that may offer hints of social structure. Architectural structures and settlement patterns form an important source for considering social structure. The architecture of buildings has been seen as representing functions related to specific social divisions, or symbolising social position or relationships (Dark 1995.97). Prior to the emergence of the earliest solid buildings that may indicate sedentary life, societies appear to have used perishable materials periodically. Therefore, the layers of ash which usually form the lowest layers of Neolithic sites could be the result of using perishable materials. This type of housing mostly indicates a transition to the Neolithic period, during which some kind of primary food storage might have been in use. If so, each community attempted to own the surrounding resources to feed its members. But as food resources were depleted, camps were separated locally, and resources were hidden from other members of the camp. Therefore, initial storage practices must have been the result of attempting to find alternative food supplies, i.e. predomestic cultivation and animal husbandry. In fact, food storage is known as a means of risk management (see Kuijt 2009). As Marion Benz (2004.28) pointed out, population growth and thus reinforced social differences may have led to territorial commitment in the Transitional Neolithic period.

In western Iran, population increases can only be estimated according to an increase in settlement numbers until further research. Although the basic steps, food resource management in particular, were taken during this long period spanning from $c$. 9500 to $8000 \mathrm{BC}$, the social structure will not be known until further evidence is discovered. But it is during the succeeding Early Neolithic that some changes are seen; in particular, architecture, burials, clay tokens, stone tools, and the introduction of some materials made of obsidian and marble are of interest.

The earliest known architectural remains include cellular rooms with a rectilinear plan. Rectilinear buildings with subdivisions offered less communality than circular rooms into which access is direct. This may strengthen privacy. It has been suggested that the appearance of these buildings coincided with the appearance of private or individual storages (Flannary 2002). This could be taken as an indicator of private ownership or property, which might have paved the way for an initial hierarchy in the Neolithic period.
Kent Flannery (1972) identified two site types in the archaeological literature - circular hut compounds and rectilinear house villages - and examined the ethnographic literature for insights into the social structure of these settlement types. Based on his considerations, early clusters or compounds of circular buildings during the Natufian and Pre-Pottery Neolithic A (PPNA) were hypothesised as representative of patrilineal, polygamous families. Each building was typically occupied not by a family, but by one or sometimes two people (typically a man or one of his wives). In later Neolithic villages, in contrast, "rectilinear buildings are designed to accommodate families, rather than individuals". These buildings of the Pre-Pottery Neolithic B (PPNB) were hypothesised as being occupied by families of three or four people. Thus, the transition from circular to rectilinear buildings coincided with a shift in residential units from polygamous to monogamous households. Nuclear households or simple households generally comprise spouses and their children, while extended families or complex households include two or more co-resident married siblings or additional adult members (Byrd 2000.66). However, the remains of circular houses are not seen in Neolithic western Iran and, as mentioned, the earliest solid houses seem to have been rectilinear in plan, which may suggest a kind of monogamous extended household in the early Neolithic period.

In general, two types of building have been defined at Neolithic sites in western Iran: residential and ritual. The former is distinguished by the nature of the internal features, the presence of in situ artefacts for food processing and preparation, and the production and maintenance of tools and other domestic equipment. It was also facilitated by storage. The two ritual buildings which have so far been discovered in the region are clearly indicated by the style of building - usually different from domestic buildings - the associated features and objects, such as animal skulls, and also the energy expended in their construction (for the criteria of Neolithic ritual buildings see Byrd 1994). These criteria have been employed by archaeologists to infer the proper ritual or symbolic function of the buildings (Smith 1990; Matthews et al. 2013a).

Gary 0. Rollefson $(1998 ; 2005)$ has divided ritual buildings into 'shrines' and 'temples'. In his view, shrines were smaller, because they might have been used by smaller groups (lineages), while temples were larger and more complex and might have served the entire community. The ritual buildings 
found in western Iran, however, indicate a tendency for sacred places to have been used by a single community or even by several settlements located close together across a geographically separated valley or plain.

The latter issue might remind us of a sort of 'ritual centrality', perhaps similar to Göbekli Tepe in southeastern Turkey (Schmidt 2005; 2011). Ritual buildings do not automatically signify inequality, but raise questions about corporate authority (Wright 2014. 7). A ritual area was not necessarily located inside the settlement. A particular sacred area close to the village might have been targeted to enact rituals. If so, it is almost undetectable archaeologically. It should also be kept in mind that a few locations, such as Ganj Dareh and Sheikh-e Abad, might have been ritually central to the surrounding settlements. Such centrality probably offered a higher status across the region.

Perhaps ritual centrality in the Neolithic period could be compared somewhat with contemporary religious centres or sacred places; each is primarily revered by particular groups of people. In western Iran, some Neolithic settlements included buildings that seem to have been more elaborate than the rest. The most costly buildings would have been the most important. According to the rank-size rule, the bigger a building, the higher was its rank. If so, ritual areas at Sheikh-e Abad and Ganj Dareh, and some other notable buildings such as those found at Guran and Chogha Sefid, may hint at rank or differentiation within the social structure of some communities. The size and height of the platforms discovered at Chogha Sefid and their standard mudbricks (see Hole 1977) could indicate a non-residential or public function.

Across the Near East, public buildings have been discovered at different Neolithic sites, such as Jerf elAhmar (Stordeur 2000), Mureybet (Cauvin 1977), Hallan Çemi (Rosenberg 1999; 2011), Çayönü (M. Özdogan 1999; A. Özdogan 2011), Göbekli Tepe (Schmidt 2005; 2011), Jericho (Kenyon 1953), Beidha (Byrd 1994), Ain Ghazal (Rollefson, Kafafi 1997), and Wadi Faynan 16 (Mithen et al. 2005). Although we are not sure about the ritual function of some of these buildings, ritual behaviours functioned to reduce tension in times of environmental stress within farming societies (Rollefson 1998; Verhoeven 2002). In addition, Ian Kuijt (2002) believes that ritual behaviours were a means of gaining authority in farming societies. Therefore, the role of ritual areas and those who were responsible for ritual matters might have been of importance in organising societies. This comes to the fore when we consider the co-emergence of public buildings and clay tokens, which may indicate the economic role of ritual areas. However, an intra-site spatial analysis can yield valuable information on the function of architectural remains, and one should examine the arrangement of space within building interiors, focusing on the location and function of internal structural features, and the nature and spatial distribution of the associated artefacts (Byrd 2000.60).

In the so-called open area at Sheikh-e Abad (Matthews et al. 2013a), close to the ritual building, a large amount of animal bone was found, presumably a hint of consumption beyond household needs. This area could also indicate a site of activity where various objects such as stone tool and bone objects were made. However, Bar-Yosef (2002.119) believes that common buildings indicate an increase in the level of social structure.

In addition, the application of lime or gypsum in architecture is also regarded as a mark of initial specialisation and social complexity (Kingery et al. 1988). As a result of her ethno-archaeological investigation, Carol Kramer (1979.148) stated that variation in the frequency and quality of floors suggests differential access to source materials and perhaps socio-economic status. However, if multi-roomed rectilinear structures indicate extended families consisting of various members, for example, grandparents, uncles, aunts etc. (Flannery 1972; Byrd 2000), they might indicate that economic activities were shared by genetically related households. These households had a tribal kinship system (see Bender 1978); although they would have shared storage facilities, situated either within only one building or as smaller adjacent storage structures (Byrd 2000.87), individual storage was emerging. Kin affiliation, however, was highly important in Neolithic villages that consisted of relatives. In the case of Sheikh-e Abad, where very small grindstones were discovered, a kind of shared area for food producing or processing may have been identified, although this may also indicate an abandonment which was not the result of a sudden event. It should be noted that reconstructing the function of prehistoric buildings is extremely difficult. The function of buildings may change over time, and the archaeological evidence may imply only the ultimate use of a building or include a compilation of signatures from a sequence of functions (Byrd 2000.67). 
It seems that household size did not radically change during the entire Neolithic period (c. 8000-5500 BC). However, a trend toward the greater use of internal space for domestic activities, storage, production, and the increased size of settlement populations is assumed. This could result in the building of some larger spaces through time; buildings of various sizes are seen in Neolithic western Iran. Perhaps smaller structures indicated smaller population numbers, seasonal use, and less reliance on domesticated plants and, hence, less need for storage and processing locations.

Beyond the intra-site level, spatial analysis could also be informative regionally. In the region, no settlement layouts have been found that are comparable in size to the mega-sites known from other areas of the Near East. It seems that variation in size resulted from the carrying capacity of the environmental resources around the sites across western Iran. Compared with a maximum of 0.5 to 1 ha as the average size in the region, however, some sites like Chogha Golan must have reached approx. 3ha in the $8^{\text {th }}$ millennium BC. As noted above, this variation in settlement size seems to correlate with resource abundance (see Hole 2000) and the ensuing population growth at the some sites, while some other settlements maintained their small area based on the available resources. This shows an adaptation to the surrounding environmental resources to support enough people in one place. However, this fact does not mean 'centrality', as proposed for the Levantine PPNB, with sites exceeding 10ha in area (see Rollefson 1998; Simmons 2007). Generally speaking, fundamental cultural changes have been attributed to the onset of the PPNB period, $c .8500-7000 \mathrm{BC}$, while the preceding PPNA period, c. 9500-8500 BC, witnessed a transition in multiple aspects of social life.

Apart from buildings and settlement layout, some artefacts could give hints on social structure. The simplest way in which artefacts are used by archaeologists to form the basis of their conclusions about social structure is by ordering them according to their value or significance as perceived by the archaeologists concerned. Artefacts may be ranked on the grounds of their materials, their scarcity, or the amount of effort required to produce them (Dark 1995.95). An artefact type may have had special value: (1) if it is made of material imported from a considerable distance; (2) if there were difficulties associated with importing; and (3) if manufacture was unusually labour intensive (Wright 2014.12).
In this regard, some objects made of obsidian and marble deserve attention. These two groups of material seem to have contemporaneously emerged around the late $8^{\text {th }}$ millennium $\mathrm{BC}$ in western Iran. It seems that obsidian was not equally valued in all places - some sites indicate higher usage than others. In the light of natural obstacles, including the mountains and deep valleys in the region, villages appear to have been unable to import obsidian directly from the sources. Therefore, some kind of intermediary trading must have been established which resulted in obsidian distribution across the region. Unlike in western Zagros, high amounts of obsidian tools were not used in the Neolithic occupations. Therefore, an indirect relationship could be assumed between south-eastern Turkey and western Iran. Here, the most probable route to import the obsidian must have been through western Zagros ( $D a$ rabi, Glascock 2013). Stefan Karol Kozłowski (1999. 63) believes that a highly specialised obsidian mining and processing system (mines and workshops) appeared in another region, perhaps in Turkey. Regarding the presence of clay tokens and public or elaborated buildings at some sites, an administrative organisation might be inferred.

Inter-regional relationships are not reflected only in obsidian trading, but also in marble, which was used to produce various objects such as ornaments and vessels. Marble objects have been found at different Neolithic sites, such as East Chia Sabz, Asiab, Genil, Guran, Ali Kosh, etc. These materials became important inter-regionally and used from $c .7200 \mathrm{BC}$ onward across the Near East (Koztowski, Aurenche 2005). Furthermore, it seems likely that finely-walled stone vessels were also produced at the same time. However, the mechanism of production and exchange organisation is unknown. Perhaps these scarce objects were used as prestige goods in Neolithic society. If so, they may reflect social differentiation, which is also detectable in some burials.

The pioneering work of Arthur Saxe (1970) and Lewis Binford (1971) opened up the analysis of mortuary practices as a primary means of investigating past social systems. Archaeologists have recently devoted considerable attention to mortuary and ritual practices as a way to reconstruct broader Neolithic social organisation and the existence of some degree of social differentiation (Kuijt 2000. 317). In western Iran, burials could help us find clues to the social structure of Neolithic people. Did the varying mortuary practices signal particular social units in society? Collective burials could indicate a collective 
identity for the society. However, finds of such burials have so far been limited to a few cases recovered from lower Guran, Abdul Hosein, and Ganj Dareh D. In addition, plastered skulls or skull removal, which is reported from sites in the Levant and Turkey, is not seen in Neolithic western Iran, where burials are mostly found underneath floors in a tightly flexed position.

As mentioned above, however, some individuals were treated differently. Perhaps some burials that were accompanied by grave goods, or wrapped in a reed mat or coated with red ochre indicate initial social ranking. In this regard, the richest example, from the Mohammad Jaffar phase, is of interest. However, diachronic changes are not clear through time, and burial traditions indicate a kind of more or less regional homogenisation of community members at the time of death.

In addition to ritual buildings and burial customs, rank is also indicated by the presence of clay tokens. Neolithic clay tokens have been widely analysed by Denise Schmandt-Besserat (1982; 1992; 1996), who attributed their emergence to around $8000 \mathrm{BC}$, describing them as the precursor of a writing system. She believes that Neolithic tokens were associated with an agricultural economy to record goods, functioning as symbols for them. In western Iran, the earliest known examples, from Ganj Dareh and Asiab, are dated to around $8000 \mathrm{BC}$ (Schmandt-Besserat 1992). Although the later part of the Neolithic period yields more clay tokens, their emergence in the Early Neolithic could indicate a sort of counting system contemporaneous with the beginning of sedentary life and ritual buildings. These innovations perhaps suggest a kind of initial administrative system and political power which relied upon controlling real goods. However, there seems to have been an inter/intra-site counting system, which outlines a regional and interregional bureaucratic relationship. Schmandt-Besserat (1992.198) determined two stages of clay systems: plain and complex. In her view, these stages correspond to two phases in the evolution of social structure. The plain tokens seen in the Neolithic period imply a ranked society, and counting was an indicator of privilege. Perhaps rituals areas functioned as places for the administration of economic activities in agricultural societies. If so, the 'temple-based economy' dates back to the beginning of the Neolithic period.

In addition to tokens, clay was also used to produce figurines (see Schmandt-Besserat 1974). It seems that the emergence of figurines should be given attention in relation to a new economic strategy based on agriculture. As more individuals could create a bigger food supply and provide better security for themselves, a higher population would become a preference. This signals the importance of higher birth rates and, therefore, females found higher social positions in society. The fact that female figurines were mostly show protrusions could mean they were fertility symbols, and an emphasis on producing more children (Voigt 2000). In addition, perhaps some particular figurines, such as seated females, were status symbols of some kind (Fig. 6). Therefore, specific symbols might have corresponded to specific ranks. In his discussion on the ritual and social structure of Ain Ghazal, Rollefson (2000. 184) believes that certainly some of the PPNB animal figurines belong in a 'toy' or analogous category, but others (particularly human and cattle figurines) appear in contexts that indicate controlled ritual usage (and perhaps production by certain shamans or other ritual practitioners). Regardless of the possible function of figurines in the Neolithic context, their spatial and temporal distribution should be considered in association with inter-related aspects of the society, including subsistence, rituality and social organisation.

While some artefacts, such as those made of marble and obsidian, may indicate inter-regional contact, some others, such as chipped stone tools, suggest local standardisation and craft specialisation. During the transitional Neolithic, a combination of Zarzian, along with the earliest signs of M'lefatian tradition, which is here referred to as 'Pre-M'lefatian tradition', is seen (see Koztowski 1994; 1996; 1999; Olszewski 1994; 1996). By the beginning of the Neolithic period, however, the M'lefatian tradition became prevalent. Although very gradual change can be traced in the Neolithic chipped industry in western Iran, stan-

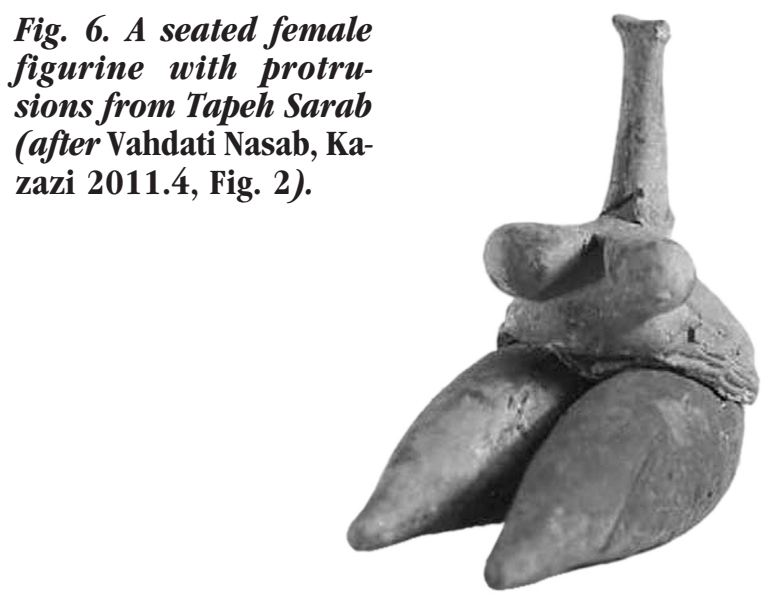


dard tools such as blades and bladelets at some sites such as upper Sheikh-e Abad (Vahdati Nasab et al. 2013) could indicate some kind of domestic specialisation. Kozłowski (1999) argued that a high-value black flint might have been traded across the region as a desirable raw material. This, alongside the standardisation of stone tools, might hint at craft specialisation, although this issue requires further investigation.

\section{Concluding remarks}

Although population numbers are difficult to reconstruct and verify, we may assume that population increase caused an increase in site numbers in western Iran. As a result, people were confronted with food shortages and, therefore, they had to manage food resources in the $9^{\text {th }}$ millennium BC. Perhaps storage pits were used in this regard in the transitional period. In addition, this might have resulted in restricted access to resources and, therefore, territoriality (for the role of territoriality, see Gebel 2014). Archaeologically, territoriality is perhaps shown by different styles of artefacts, although some were shared at a regional or inter-regional level. For example, we may observe the presence of particular objects such as some distinct pottery styles in many areas, while others were restricted to a specific area. These ideas address both local 'micro-packages', each formed by a combination of local natural, social, and cognitive environments, and regionally-shared 'macro packages' in Neolithic western Iran. In the Neolithic period, however, the long-term storage of grain paved the way for private property and a reduction in reciprocity. In other words, some degree of property implies a departure from the generalised reciprocal sharing typical of mobile hunter-gatherer societies. Therefore, seasonal surpluses, when coupled with private storage and increasing agriculture, laid the foundation for the earliest steps toward social complexity. Generally speaking, the transition to agriculture probably coincided with a transition from common property to the earliest signs of private property.

At a regional level, archaeological evidence shows the emergence of fully domesticated species around $8000 \mathrm{BC}$, when the true Neolithic period began. This period witnessed the first signs of sedentism, with solid architecture, ritual or common buildings, clay tokens, and inter-regional contacts. It should be noted that at least some minimal level of social complexity is present in virtually any sedentary society (Rosenberg, Redding 2000.39). Increasing empha- sis on agriculture was consistent with the increased use of grindstones (Wright 1994). If grindstones are found within domestic spaces, they may indicate self-sufficient food production and a kind of private property. On the other hand, if they are found in a non-domestic or common area, we may take them as indicators of their communal use or even collective food production. Although clusters of milling tools have been regarded as indicators of mass food preparation (Asouti, Fuller 2013; Hayden, 2009; Willcox, Stordeur 2012), we are not sure this happened at some particular sites such as Chogha Golan, which have yielded amounts of grinding stones.

Private storage and food production signal ownership in the Early Neolithic. However, the possible role of ritual places should not be overlooked. Consideration of Neolithic architecture, mortuary practices and ritual actions collectively brings researchers to the point where we can start to reflect on how ritual and civic leadership might have been organised in different Neolithic communities (Kuijt 2000.317). Ritual buildings seem to have appeared in the early Neolithic at the same time as clay tokens. The authority of ritual practitioners should be economically and ritually placed within an intra/intersite framework. If these ritual centres, along with clay tokens, indicate an initial administrative system, they may be regarded as a sort of preliminary to institutionalisation. Perhaps the presence of clay tokens at some settlements shows an inter/intra-site redistributive system organised by ritual practitioners. Therefore, the two-fold role of ritual places might indicate a kind of 'temple economy'. Ritual activities were structured at three levels inside a community: individual, household, and intra-community (Verhoeven 2002). In addition, an inter-site level was also possible. A few sites contain evidence indicating ritual areas in western Iran. This may suggest a 'regional centrality' in the way that each centre, such as Sheikh-e Abad, was regarded at an intersite level. Besides ritual buildings, some other elaborate architecture, such as at Guran or Chogha Sefid, could be evidence of social differentiation. Generally, social differentiation may be identified by two processes: one related to trade, exchange and societal interaction, and another to the intensification and specialisation of production of agriculture and crafts and subsequently their management and control. The emergence of some scarce artefacts, including obsidian pieces and marble objects, indicate inter-regional interaction since the late $8^{\text {th }}$ millennium $\mathrm{BC}$ onward. We are not in a position to say whether these objects were used by individuals in specific 
areas or times or used as common material. The regional circulation of prestige goods is not clear. If the materials found within buildings are similar, they may mean the community was self-sufficient; if not, it would indicate cooperation and sharing, or inequality of access (Wright 2014.16). Intra or intersite inequality of access to resources affects the social status.

In the Levantine PPNB period, stable isotope data from burials revealed possible differential food consumption patterns and may indicate social complexity (Pearson et al. 2013). Different access to food resources could pave the way for social conflict. Social conflicts have not yet been inferred, although it has been supposed that Ganj Dareh D might have been burnt as the result of such an event (Smith 1976; Bar-Yosef 2009.206). In this regard, Frank Hole (1987.33) stated that some hunters maintained their ways of life alongside the early villagers for a considerable time in some areas and they must have been mutually influential, some cooperatively, some antagonistically; in the latter case by poaching herds or stealing crops stored in the villages. This may have stimulated the nucleation of settlements and eventually the construction of defensive structures. If this was the case, the thick clay wall discovered at Sheikh-e Abad may be meaningful, hinting at a kind of fortified occupation in the $8^{\text {th }}$ millennium BC. It should be noted that fortified Neolithic villages have already been found across the Central Plateau of Iran (see Malek Shahmirzadi 2006) and Northern Mespotamia (Matthews 2000). This suggestion, however, could open a new window into further invaluable information on the social structure of Neolithic societies in western Iran.

Social, economic, political and religious territories might have been established within Neolithic societies, although they have always been intertwined. In fact, through artefacts people recreate their material world and their social relations. Material cul- ture is known as a principal means of identification and distinction from 'the others' (Balossi Restelli 2006). For instance, to discuss the pottery found from the Neolithic site of Toll-e Bashi, Southern Zagros, Bernbeck et alii (2003.78) believe that the strong focus on one motif may have served a social function, unifying members of the community and setting them apart from neighbouring ones. However, people tended to perceive themselves as individuals differently from adjacent regions across the Near East. It seems that Neolithic people attempted to manifest their particular identity through making the particular artefacts seen in different archaeological sites in western Iran. At the same time, they shared some common artefacts or ideas which might have been produced by each group separately or, but with the same popular tradition, traded throughout the region. Small variations in burial customs, therefore, may show religious differences between those buried, or those burying them, or differences between local customs across the region. Moreover, some burials may be expressions of social status. This discussion explicitly concerns the two kinds of synchronous micro/macro-packages in Neolithic western Iran mentioned above.

Finally, it should be emphasised that, despite the fact that some archaeological evidence such as buildings, burials, and other artefacts hint at the social structure of Neolithic western Iran, our information is obviously limited. This prevents us from taking steps in more detail in this area of research until further information becomes available.

I would like to express my gratitude to Prof. P. Mortensen and Dr. T. Richter for their insightful comments on the earlier draft of the article. Also, Dr. S. Alibaigi, Dr. A. Javanmardzadeh and Prof. R. Matthews made some helpful points. 


\section{References}

Abdi K. 2004. Obsidian in Iran from the Epipaleolithic Period to the Bronze Age. In T. Stollner, R. Slotta and A. R. Vatandost (eds.), Splendor of Iran. Bochum: 148-153.

Ali N. 2010. The Restructuring of Socio-Economic Relations during the LPPNB in the Southern Levant and the Role of Ritual Buildings. Jordanian Journal of History and Archaeology 4(1): 159-188.

Asouti E., Fuller D. 2013. A Contextual Approach to the Emergence of Agriculture in Southwest Asia. Current Anthropology 54(3): 299-345.

Balossi Restelli F. 2006. The Development of 'Cultural Regions' in the Neolithic of the Near East, The Dark Faced Burnished Ware Horizon. British Archaeological Reports IS 1482. Archaeopress. Oxford.

Bar-Yosef 0. 2001. From Sedentary Foragers to Village Hierarchies: the Emergence of Social Institutions. In G. Runciman (ed.), The Origin of Human Social Institutions. Royal Society and British Academy. London: 1-38.

2002. The Natufian Culture and the Early Neolithic: Social and Economic Trends in Southwestern Asia. In P. Bellwood, C. Renfrew (eds.), Examining the Farming/ Language Dispersal Hypothesis. McDonald Institute Monographs. University of Cambridge. Cambridge: 113126.

2009. Social Changes Triggered by the Younger Dryas and the Early Holocene Climatic Fluctuation in the Near East. In C. T. Fisher, J. B. Hill and G. M. Feinman (eds.), The Archaeology of Environmental Change. The University of Arizona Press. Tucson: 193-208.

Bar-Yosef O., Belfer-Cohen A. 1991. From Sedentary Hunter-Gatherers to Territorial Farmers in the Levant. In S. A. Gregg (ed.), Between Bands and States. Center for Archaeological Investigations. Carbondale: 181-202.

Bender B. 1978. Gatherer-Hunter to Farmer: A Social Perspective. World Archaeology 10(2): 204-222.

Bendrey R., Cole G. and Tvetmarken C. L. 2013. Zooarchaeology: Preliminary Assessment of the Animal Bones. In R. Matthews, W. Matthews and Y. Mohammadifar (eds.), The Earliest Neolithic of Iran: 2008 Excavations at Sheikh-e Abad and Jani: Central Zagros Archaeological Project. Oxbow Books. Oxford: 147-158.

Benz M. 2004. The Emic View: Social Questions of the Neolithisation of the Near East. Neo-Lithics 1(4): 27-28.

Bernbeck R., Pollock S. and Abdi K. 2003. Reconsidering the Neolithic at Toll-e Bashi (Iran). Near Eastern Archaeo$\log y$ 66(1/2): 76-78.
Binford L.R. 1971. Mortuary Practices: their Study and their Potential. In J. A. Brown (ed.), Approaches to the Social Dimensions of Mortuary Practices. American Anthropological Association. Washington: 58-67.

Bleda S. D., Marciniak A. 2006. Households and Communities in the Central Anatolian Neolithic. Archaeological Dialogues 12(2): 165-187.

Braidwood R. J. 1960. Preliminary Investigations Concerning the Origins of Food Production in Iranian Kurdistan. British Association, Advancement of Science 17: 214-218.

1961. The Iranian Prehistoric Project. Iranica Antiqua 1: 3-7.

Braidwood R. J., Howe B. and Reed C. 1961. The Iranian Prehistoric Project. Science 133: 2008-2010.

Byrd B. F. 1994. Public and Private, Domestic and Corporate: the Emergence of the Southwestern Asian Village. American Antiquity 59: 639-666.

2000. Households in Transition Neolithic Social Organization within Southwest Asia. In I. Kuijt (ed.), Life in Neolithic Farming Communities: Social Organization, Identity, and Differentiation. Kluwer Academic/Plenum Publishers. New York: 63-98.

2005. Reassessing the Emergence of Village Life in the Near East. Journal of Archaeological Research 13(3): 231-290.

Cauvin J. 1977. Les Fouilles de Mureybet (1971-1974) et Leur Signification pour les Origines de la Sedentarisation au Proche-Orient. Bulletin of the American Schools of Oriental Research 44: 19-48.

2000. The Birth of the Gods and the Origins of Agriculture. Translated into English by T. Watkins. Cambridge University Press. Cambridge.

Childe G. V. 1936. Man Makes Himself. Mentor. New York.

Cole G. 2013. Human Burials. In R. Matthews, W. Matthews and Y. Mohammadifar (eds.), The Earliest Neolithic of Iran: 2008 Excavations at Sheikh-e Abad and Jani: Central Zagros Archaeological Project. Oxbow Books. Oxford: $163-174$.

Darabi H. 2012. Towards Reassessing the Neolithisation Process in Western Iran. Documenta Praehistorica 38: 103-110. 
2015. An Introduction to the Neolithic Revolution in the Central Zagros. British Archaeological Reports IS 2746. Archaeopress. Oxford.

Darabi H., Fazeli H., Naseri R., Riehl S. and Young R. 2013. The Neolithisation Process in the Seimareh Valley: Excavations at East Chia Sabz, Central Zagros. In R. Matthews, H. Fazeli Nashli (eds.), The Neolithisation of Iran, The Formation of New Societies. Oxbow Books, Oxford: 5575.

Darabi H., Glascock M. 2013. The Source of Obsidian Artefacts Found at East Chia Sabz, Western Iran. Journal of Archaeological Science 40: 3804-3809.

Darabi H., Naseri R., Young R. and Fazeli H. 2011. Absolute Chronology of East Chia Sabz: A Pre-Pottery Neolithic site in Western Iran. Documenta Praehistorica 39: 255-265.

Dark K. R. 1995. Theoretical Archaeology. Cornell University Press. New York.

Flannery K. V. 1972. The Origin of the Village as a Settlement Type in Mesoamerica and the Near East. In P. J. Ucko, R. Tringham and G. W. Dimbleby (eds.), Man, Settlement and Urbanism. Duckworth. London: 23-53.

2002. The Origins of the Village Revisited: From Nuclear to Extended Households. American Antiquity 67(3): 417-433.

Gebel H. G. K. 2014. Territoriality in Early Near Eastern Sedentism. Neo-Lithics 2(14): 23-44.

Goring-Morris A. N. 2000. The Quick and the Dead: The Social Context of Aceramic Neolithic Mortuary Practices as Seen from Kfar HaHoresh. In I. Kuijt (ed.), Life in Neolithic Farming Communities: Social Organization, Identity, and Differentiation. Kluwer Academic/Plenum Publishers. New York: 103-136.

Hayden B. 2009. The Proof is in the Pudding: Feasting and the Origins of Domestication. Current Anthropology 50(5): 597-601.

Hodder I. 2007. The "Social" Archaeological Theory: An Historical and Contemporary Perspective. In L. Meskell, R. W. Preucel (eds.), A Companion to Social Archaeology. Blackwell Publishing Ltd. Makden, Oxford, Carlton: 23-42.

Hole F. 1977. Studies in the archaeological history of the Deh Luran Plain: The Excavation of Chogha Sefid. Ann Arbor. Michigan.

1987. The Archaeology of Western Iran. Smithsonian series in Archaeological Inquiry. Smithsonian Institution Press. Washington.
2000. Is Size Important? Function and Hierarchy in Neolithic Settlements. In I. Kuijt (ed.), Life in Neolithic Farming Communities: Social Organization, Identity, and Differentiation. Kluwer Academic/Plenum Publishers. New York: 191-209.

Hole F., Flannery K. V. and Neely J. A. 1969. Prehistory and Human Ecology on the Deh Luran Plain. Memoirs of the Museum of Anthropology 1. The University of Michigan Press. Ann Arbor.

Howe B. 1983. Karim Shahir. In L. S. Braidwood, R. J. Braidwood, B. How, C. A. Reed and P. J. Watson (eds.), Prehistoric archaeology along the Zagros flanks. The Oriental institute of the University of Chicago 105. University of Chicago. Chicago: 23-154.

Kenyon K. M. 1953. Excavations at Jericho, 1953. Palestine Exploration Quarterly 85: 81-95.

Kingery W. D., Vandiver P. B. and Prickett M. 1988. The Beginning of Pyro-technology, Part II: Production and Use of Lime and Gypsum Plaster in the Pre-Pottery Neolithic Near East. Journal of Field Archaeology 15: 219-244.

Kozłowski S. K. 1994. Chipped Neolithic industries at eastern wing of the Fertile Crescent (Synthesis Contribution). In H. G. Gebel, S. K. Kozłowski (eds.), Neolithic Chipped Stone Industries of the Fertile Crescent. Studies in Early Near Eastern Production, Subsistence, and Environment 1. ex Oriente. Berlin: 143-171.

1996. From Zawi Chemi to M'lefaat. In S. K. Kozłowski, H. G. Gebel (eds.), Neolithic Chipped Stone Industries of the Fertile Crescent and their Contemporaries in Adjacent Regions. Studies in Early Near Eastern Production, Subsistence, and Environment 3. ex Oriente. Berlin: 175-182.

1999. The Eastern Wing of the Fertile Crescent: Late Prehistory of Greater Mesopotamian Lithic Industries. British Archaeological Reports IS 760. Archaeopress. Oxford.

Kozłowski S. K., Aurenche 0. 2005. Territories, Boundaries and Cultures in the Neolithic Near East. British Archaeological Reports IS 1362. Archaeopress. Oxford.

Kramer C. 1979. Ethnoarchaeology: Implications of Ethnography for Archaeology. Columbia University Press. New York.

Kuijt I. 2000. Near Eastern Neolithic Research, Directions and Trends. In I. Kuijt (ed.), Life in Neolithic Farming Communities: Social Organization, Identity, and Differentiation. Kluwer Academic/Plenum Publishers. New York: 312-322. 
2002. Reflections on Ritual and the Transmission of Authority in the Pre-Pottery Neolithic of the Southern Levant. In H. Gebel, B. Hemansen and H. Jensen (eds.), Magic, Practices and Ritual in the Near Eastern NeOlithic: Proceedings of a Workshop Held at the $2^{\text {nd }}$ International Congress on the Archaeology of the Ancient Near East (ICAANE), Copenhagen University, May 2000. Studies in Early Near Eastern Production, Subsistence and Environment 8. ex Oriente. Berlin: 81-90.

2009. What Do We Really Know about Food Storage, Surplus, and Feasting in Preagricultural Communities? Current Anthropology 50(5): 641-644.

Kuijt I., Goring-Morris N. 2002. Foraging, Farming, and Social Complexity in the Pre-Pottery Neolithic of the Southern Levant: A Review and Synthesis. Journal of World Prehistory 16(4): 361-440.

Malek Shahmirzadi S. 2006. Sialk, the Oldest Fortified Village of Iran. Iranian Center for Archaeological Research. Tehran.

Matthews R. 2000. Early Prehistory of Mesopotamia, ca. 500,000 to 4,500 BC. Subartu V, Brepols. Turnhout.

Matthews R., Matthews W. and Mohammadifar Y. $2013 \mathrm{a}$. The Earliest Neolithic of Iran: 2008 Excavations at Tappeh Sheikh-e Abad and TappehJani: Central Zagros Archaeological Project. Oxbow Books. Oxford.

Matthews R., Mohammadifar Y., Matthews W. and Motarjem A. 2013b. Investigating the Neolithisation of Society in the Central Zagros of Western Iran. In R. Matthews, H. Fazeli Nashli (eds.), The Neolithisation of Iran, The Formation of New Societies. Oxbow Books. Oxford: 14-34.

McDonald M. M. A. 1979. An examination of mid-Holocene settlement patterns in the Central Zagros region of western Iran. Unpublished PhD thesis. Department of Anthropology. University of Toronto. Toronto.

Mithen S. J., Finlayson B. and Shaffrey R. 2005. Sexual Symbolism in the Early Neolithic of the Southern Levant: Pestles and Mortars from WF16. Documenta Praehistorica 32: 103-110.

Mortensen P. 1972. Seasonal Camps and Early Villages in the Zagros. In P. J. Ucko, R. Tringham and G. W. Dimbleby (eds.), Man, Settlement and Urbanism. Gerald Duckworth \& Co Ltd. London: 293-297.

1974. A Survey of the Prehistoric Settlements in Northern Luristan. Acta Archaeologica 45: 1-47.

1988. A Note on a Small Box with Flint Blades and Arrowheads from Beidha, and its Implications. In A. N. Garrad, H. G. Gebel (eds.), The Prehistory of Jordan,
The State of Research in 1986. British Archaeological Reports IS 396. Archaeopress. Oxford: 199-207.

2014. Excavations at Tepe Guran: the Neolithic Period. Acta Iranica 55. Peeters. Leuven.

Mortensen P., Smith P. E. L. 1977. A Survey of Prehistoric Sites in the Harsin Region, 1977. In F. Bagherzadeh (ed.), Proceedings of the VIth Annual Symposium on Archaeological Research in Iran. Unpublished. Tehran: 1-23.

2014. A Survey of Prehistoric Sites in the Harsin Region, 1977. Modares Archaeological Research 5/6 (10/11): $1-10$.

Olszewski D. I. 1994. The Late Epipaleolithic Chipped Stone "Heritage" in early Aceramic Neolithic Assemblages in the Northern Fertile Crescent. In H. G. Gebel, S. K. Kozłowski (eds.), Neolithic Chipped Stone Industries of the Fertile Crescent. Studies in Early Near Eastern Production, Subsistence, and Environment 1. ex Oriente. Berlin: 83-90.

1996. The Lithic Transition to the Early Neolithic in the Zagros Region: Zarzian and M'lefatian Industries. In S. K. Kozłowski, H. G. Gebel (eds.), Neolithic Chipped Stone Industries of the Fertile Crescent and their Contemporaries in Adjacent Regions. Studies in Early Near Eastern Production, Subsistence, and Environment 3. ex Oriente. Berlin: 183-92.

Özdoğan A. E. 2011. Cayönü. In M. Özdoğan, N. Başgelen and P. Kuniholm (eds.), Neolithic in Turkey, The Tigris Basin. Archaeology and Art Publications. Istanbul: 185269.

Özdoğan M. 1999. Cayönü. In M. Özdoğan, N. Başgelen (eds.), Neolithic in Turkey: Cradle of Civilization, New Discoveries. Arkeoloji ve Sanat Yayinlari. Istanbul: 35-63.

Pearson J. A., Grove M., Özbek M. and Hongo H. 2013. Food and Social Complexity at Çayönü Tepesi, Southeastern Anatolia: Stable Isotope Evidence of Differentiation in Diet According to Burial Practice and Sex in the Early Neolithic. Journal of Anthropological Archaeology 32: 190-211.

Pollock S., Bernbeck R. and Abdi K. 2010. Excavations at Tole Bashi, Fars, Iran (2003). Verlag Philipp von Zabern. Mainz.

Pullar J. 1990. Tepe Abdul Hosein, A Neolithic Site in Western Iran, Excavations 1978. British Archaeological Reports IS 563. Archaeopress. Oxford.

Renfrew C. L. 1969. The Sources and Supply of the Deh Luran Obsidian. In F. Hole, K. V. Flannery and J. A. Neely (eds.), Prehistory and Human Ecology on the Deh Luran Plain. Memoirs of the Museum of Anthropology 1. The University of Michigan Press. Ann Arbor: 429-434. 
Renfrew C. L., Dixon J. E. 1977. Obsidian in Western Asia: A Review. In G. de G. Sieveking, I. H. Longworth and K. E. Wilson (eds.), Problems in Economic and Social Archaeology. Westview Press. Boulder: 137-150.

Riehl S., Asouti E., Karakaya D., Starkovich B. M., Zeidi M. and Conard N. J. 2015. Resilience at the Transition to Agriculture: The Long-Term Landscape and Resource Development at the Aceramic Neolithic Tell Site of Chogha Golan (Iran). BioMed Research International 2015: 1-22.

Riehl S., Benz M., Conard N., Darabi H., Deckers K., Fazeli H. and Zeidi M. 2012. Plant use in three Pre-Pottery Neolithic Sites of the Northern and Eastern Fertile Crescent: A Preliminary Report. Vegetation History and Archaeobotany 21(2): 95-106.

Riehl S., Zeidi M. and Conard N. 2013. Emergence of Agriculture in the Foothills of the Zagros Mountains of Iran. Science 341: 65-67.

Rollefson G. 1998. Ain Ghazal (Jordan): Ritual and Ceremony III. Paléorient 24(1): 43-58.

2000. Ritual and Social Structure at Neolithic Ain Ghazal. In I. Kuijt (ed.), Life in Neolithic Farming Communities: Social Organization, Identity and Differentiation. Kluwer Academic/Plenum. New York, London: 163-190.

2005. Early Neolithic Ritual Centers in the Southern Levant. Neo-Lithics 2(5): 3-13.

Rollefson G., Kafafi Z. 1997. The 1996 Season at 'Ayn Ghazal: Preliminary Report. Annual of the Department of Antiquities of Jordan 41: 27-49.

Rosenberg M. 2011. Hallan Çemi. In M. Özdoğan, N. Başgelen and P. Kuniholm (eds.), Neolithic in Turkey, The Tigris Basin. Archaeology and Art Publications. Istanbul: 61-78.

Rosenberg M. 1999. Hallan Çemi. In M. Özdoğan, N. Başgelen (eds.), Neolithic in Turkey: Cradle of Civilization, New Discoveries. Arkeoloji ve SanatYayinlari. Istanbul: 25-33.

Rosenberg M., Redding R. W. 2000. Hallan Çemi and Early Village Organization in Eastern Anatolia. In I. Kuijt (ed.), Life in Neolithic Farming Communities: Social Organization, Identity And Differentiation. Plenum Press. New York: 39-61.

Sahlins M. 1968. Notes on the Original Affluent Society. In R. B. Lee, I. DeVore (eds.), Man the Hunter. Aldine. Chicago: $85-89$.

Saxe A. 1970. Social Dimensions of Mortuary Practices. Unpublished PhD thesis. University of Michigan. Ann Arbor.
Schmandt-Besserat D. 1974. The Use of Clay before Pottery in the Zagros. Expedition 18(2): 11-17.

1982. The Emergence of Recording. American Anthropologist 84(4): 871-878.

1992. Before Writing. University of Texas Press. Austin.

1996. How Writing Came About. University of Texas Press. Austin.

Schmidt K. 2005. "Ritual Centers" and the Neolithisation of Upper Mesopotamia. Neo-Lithics 2(5): 13-21.

2011. Göbekli Tepe. In M. Özdoğan, N. Başgelen and P. Kuniholm (eds.), Neolithic in Turkey, The Euphrates Basin. Archaeology and Art Publications. Istanbul: 4183.

Service E. 1964. Primitive Social Organization: An Evolutionary Perspective. Random House. New York.

Shanks M. 2005. Social Archaeology. In C. Renfrew, P. Bahn (eds.), Archaeology: The Key Concepts. Routledge. London, New York: 179-181.

Simmons A. H. 2007. The Neolithic Revolution in the Near East: Transforming the Human Landscape. The University of Arizona Press. Tucson.

Smith P. E. L. 1972. Ganj DarehTepe. Iran 10: 165-168.

1990. Architectural Innovation and Experimentation at Ganj Dareh, Iran. World Archaeology 21(3): 323-335.

1976. Reflection on Four Seasons of Excavations at Tappeh Ganj Dareh. In F. Bagherzadeh (ed.), Proceeding of the $4^{\text {th }}$ Annual Symposium on Archaeological Research in Iran. Tehran: 11-22.

Smith P. E. L., Mortensen P. 1980. Three New Early Neolithic Sites in Western Iran. Current Anthropology 21(4): 511-512.

Stordeur D.2000. New discoveries in Architecture and Symbolism at Jerf el-Ahmar (Syria), 1997-1999. Neo-L $i$ thics 1(0): 1-4.

Vahdati Nasab H., Kazzazi M. 2011. Metric Analysis of a Female Figurine from Tepe Sarab. Iran 49: 1-10.

Vahdati Nasab H., Jayez M., Qorbani H. R., Darabi H. and Taylor H. 2013. Preliminary Techno-typological Analysis of Chipped Stone Materials from Sheikh-e Abad. In R. Matthews, W. Matthews and Y. Mohammadifar (eds.), The Earliest Neolithic of Iran: 2008 Excavations at Sheikh-e Abad and Jani: Central Zagros Archaeological Project. Oxbow Books. Oxford: 117-130. 
Verhoeven M. 2002. Transformation of Society: the Changing Role of Ritual and Symbolism in the PPNB and PN in the Levant, Syria and South-east Anatolia. Paléorient 28(1): 5-14.

Voigt M. M. 2000. Çatal Höyük in Context: Ritual at Early Neolithic Sites in Central and Eastern Turkey. In I. Kuijt (ed.), Life in Neolithic Farming Communities: Social Organization, Identity, and Differentiation. Kluwer Academic/ Plenum Press. New York: 253-294.

Weeks L. 2013. The Development and Expansion of a Neolithic way of Life. In D. T. Potts (ed.), Oxford Handbook of Ancient Iran. Oxford University Press. Oxford: 49-75.

Willcox G., Stordeur D. 2012. Large-scale Cereal Processing before Domestication during the Tenth Millennium cal BC in Northern Syria. Antiquity 86: 99-114.
Wright K. 2014. Domestication and Inequality? Households, Corporate Groups and Food Processing Tools at Neolithic Çatalhöyük. Journal of Anthropological Archaeology 33: 1-33.

Zeder M. A. 2008. Animal Domestication in the Zagros: An Update and Directions for Future Research. In E. Vila, L. Goucherin, A. Choyke and H. Buitenhuis (eds.), Archaeozoology of the Near East VIII. Travaux de la Maison de l'Orient et de la Méditerranée (TMO). Lyon: 243-278.

2011. The Origins of Agriculture in the Near East. Current Anthropology 52 (Supplement 4): 221-236. 
